\title{
СТАТЕВИЙ РОЗВИТОК УМОВНО СОМАТИЧНО ЗДОРОВИХ ДІВЧАТОК ЛЬВІВСЬКОЇ ОБЛАСТІ В ПУБЕРТАТНИЙ ПЕРІОД
}

\author{
Львівський національний медичний університет імені Данила Галицького, м. Львів, Україна
}

\begin{abstract}
Мета: оцінити статевий розвиток умовно соматично здорових дівчаток Львівської області в період пубертату.
Матеріали і методи. Обстежено 180 умовно соматично здорових дівчаток Львівської області віком від 12 до 17 років. Проведено антропометричні дослідження (визначення маси тіла і розрахунок показника індексу маси тіла, вимірювання зросту, окружності грудної клітки, талії, стегон) і оцінку статевого розвитку за сукупністю розвитку вторинних статевих ознак (волосистості на лобку і в пахвовій ділянці, розвитку молочних залоз і становленням менструацій за J. М. Tanner і Л. Г. Тумилович).

Результати. Статеве дозрівання умовно соматично здорових дівчаток Львівської області в 92,78 \% випадків починалося 3 телархе. Середній вік настання телархе склав $(10,34 \pm 0,05)$ року, адренархе - $(11,13 \pm 0,05)$ року, аксилархе - $(11,59 \pm 0,07)$ року, менархе - $(12,43 \pm 0,04)$ року. Характерною рисою був розвиток телархе разом 3 пубархе в 51,67 \% дівчаток і аксилархе з пубархе - у 39,44 \% дівчаток. Менархе, як правило, наставало після телархе, пубархе і аксилархе, при середній масі тіла не менше за 37 кг, найчастіше на тлі ще недостатньо розвинених вторинних статевих ознак. У 3,33 \% випадків спостерігали інвертований пубертат, тобто пубархе випереджало телархе. У 5,00 \% дівчаток аксилархе відставало від пубархе на 12 місяців, у 55,00 \% - на 3-6 місяців, а в 40,00 \% дівчаток воно наставало одночасно з пубархе. Темпи статевого дозрівання в період із 12 до 17 років були відносно сталими, про що свідчить і величина сумарного бала статевого розвитку в 12-, 13-, 14-, 15-, 16- і 17-річних дівчат - рівні бала статевого розвитку, відповідно, були $(4,94 \pm 0,37),(7,91 \pm 0,58),(11,08 \pm 0,25),(11,25 \pm 0,20)$, $(11,86 \pm 0,10)$ і $(11,98 \pm 0,02)$ бала.
\end{abstract}

Висновки. Статевий розвиток умовно соматично здорових дівчаток Львівської області відповідає встановленим віковим нормам української популяції.

КЛЮчОВІ СЛОВА: дівчата; Львівська область; фрізичний розвиток; статеве дозрівання; телархе; адренархе; аксилархе; менархе.

У концепції охорони репродуктивного здоров'я особливе місце відводиться проблемам підліткового віку - віку, коли йдуть найбільш активні процеси росту, формування біологічної статевої зрілості. Статеве дозрівання було предметом досліджень з середини XX століття, і незабаром після цього його вивчення стало за своєю суттю міждисциплінарною галуззю. Наукові відкриття 3 медицини, психології, біології тварин і епідеміології мають вирішальне значення для розуміння початку і нормативного розвитку статевого дозрівання, його гормональних основ, а також потенційних коротко- і довгострокових ефектів несвоєчасного дозрівання [2, 6, 8]. Комітет експертів ВОО3 стверджує, що підлітковий вік становить від 10 до 20 років. Однак $є$ істотні відмінності у віці його початку, швидкості розвитку і віці зрілості. У термінах настання пубертатного періоду відзначаються значні індивідуальні відхилення. Дослідження показали, що початок і розвиток статевого дозрівання насамперед контролюється взаємодією генетичних фракторів і фракторів навколишнього середовища $[1,14,15]$, тому представляє інтерес оцінка статевого розвитку дівчаток на певній території проживання.

Мета дослідження: оцінити статевий розвиток умовно соматично здорових дівчаток Львівської області в період пубертату.

Матеріали і методи. Обстежено 180 умовно соматично здорових дівчаток Львівської області віком від 12 до 17 років. Ступінь статевого розвитку визначали загальноприйнятим методом за сукупністю розвитку вторинних статевих ознак: волосистості на лобку і в пахвовій ділянці, розвитку молочних залоз і становленням менструацій за J. М. Tanner (1962) і Л. Г. Тумилович (1975) [13]. При цьому відповідну ознаку оцінювали за стадією їі розвитку (0, 1, 2 і 3), яку виражали в балах.

Розвиток молочної залози (Mammae - Ma) оцінювали таким чином: МаO - молочна залоза не видається, сосок підіймається над навколососковою ареолою; Мa1 - залоза лише видається, утворює з соском конус - «стадія бутона»; Ма2 залоза значно видається разом зі соском, має фрорму конуса; Ма3 - залоза має округлу фрорму, на широкій основі, сосок здіймається над навколососковою ареолою. 
При оцінці розвитку волосся на лобку (Pubis - P) вважали Р0 як відсутність росту волосся; Р1 як поодиноке пряме волосся в центрі лобка та на великих статевих губах; Р2 - як волосся, що в'ється на лобку та на великих статевих губах; Р3 - як густе волосся, що в'ється по всій площині лобка, на сороміцьких губах.

Ріст волосся у пахвинних ділянках (Axillaris Ах) оцінювали таким чином: АхО - відсутність росту волосся; Ах1 - поодиноке волосся; Ах2 волосся більш густе на центральній ділянці пахвової западини; Ах3 - густе волосся по всій пахвовій западині.

Становлення менструальної функції (Menstruacia - Me) характеризували як Ме0 - менструації відсутні; Ме1 - наявність 1-2 менструацій до моменту огляду; Me2 - несталий менструальний цикл (нерегулярні менструації, є варіантом норми 1 рік після настання менархе; Ме3 - регулярні менструації.
Для комплексної оцінки статевого розвитку застосовували методику підсумовування балів за Л. Г. Тумилович та співавт. (1975) [3], що враховує ступінь розвитку кожної з вторинних статевих ознак. Відповідно до цього, перераховані вище ознаки оцінювали 3 урахуванням поправкового коефріцієнта. Коефріцієнт для молочних залоз склав 1,2, для ступеня оволосіння лобка 0,3, для пахвового оволосіння - 0,4, для оцінки менструальної фрункції - 2,1. Бал розвитку кожної окремої ознаки розраховували як добуток середньої кількісної оцінки вторинної статевої ознаки або менструацій на ступінь розвитку кожної ознаки у даної пацієнтки [3]. Сума балів розвитку кожної окремої ознаки склала бал статевого розвитку (БСР). Цей бал порівнювали з оцінкою бала ступеня статевого розвитку дівчаток пубертатного віку згідно з існуючими методичними рекомендаціями [3] і визначали ступінь статевого розвитку з урахуванням віку менархе (табл. 1).

Таблиця 1. Оцінка ступеня статевого розвитку дівчаток пубертатного віку

\begin{tabular}{|c|c|c|c|}
\hline \multirow{2}{*}{$\begin{array}{c}\text { Бал статевого } \\
\text { розвитку }\end{array}$} & \multicolumn{3}{|c|}{ Календарний вік менархе } \\
\cline { 2 - 4 } & в 11 років & в 13 років & в 14,5 і більше років \\
\hline 1,2 & 8 & 10 & 12 \\
\hline 2,7 & 9 & 11 & 14 \\
\hline 4,6 & 10 & 12 & 15 \\
\hline 7,1 & 11 & 13 & 16 \\
\hline 11,6 & 12 & 14 & 17 \\
\hline
\end{tabular}

Антропометричні обстеження включали вимірювання зросту, визначення маси тіла і розрахунок показника індексу маси тіла (IMT) за форомулою [маса тіла (кг)/зріст $\left.\left(\mathrm{M}^{2}\right)\right]$. Вимірювання окружності грудної клітки (ОГК), талії (ОТ), стегон (ОС) проводили стійкою до розтягування сантиметровою стрічкою відповідно до рекомендацій BOO3.

Результати дослідження були піддані статистичній обробці методом варіаційної статистики. Розраховували М - середнє значення, SE - похибку стандартного відхилення. Достовірність відмінностей оцінювали за критерієм Фішера - Стьюдента, вважаючи їх достовірними при $p<0,05$.

Результати дослідження та їх обговорення. При оцінці фрізичного розвитку умовно соматично здорових дівчаток Львівської області виявлено стрибок їх зростання у 12-річному віці, напередодні менархе, коли збільшення довжини тіла склало у більшості випадків 8-11 см (з коливаннями довжини тіла від 140 до 167 см). Наступний пубертат характеризувався невеликим постійним збільшенням довжини тіла на 1-2 см. Протягом всього пубертатного періоду маса тіла дівчаток збільшувалася поступово і в міру. Приріст маси тіла в ці роки становив 3-4 кг на рік, в середньо- му - $(3,65 \pm 0,69)$ кг. Так само, як і для збільшення тіла в довжину, для маси тіла дівчаток критичним був вік 12-13 років, коли середній приріст маси тіла за рік склав у середньому $(6,53 \pm 0,71)$ кг. У 14-річному віці приріст маси тіла дорівнював 4-5 кг (з коливаннями маси тіла від 46 до 58 кг) і в середньому був $(4,90 \pm 0,65)$ кг. У 17 років знову відбувся приріст маси тіла на $(2,83 \pm 0,67)$ кг (з коливаннями маси тіла від 47 до 65 кг) (табл. 2).

Статеве дозрівання умовно соматично здорових дівчаток Львівської області в 92,78 \% (167) випадків починалося 3 телархе, в тому числі у 51,67 \% (93) дівчаток - одночасно з пубархе. У подальшому після телархе (у 26,67 \% (48) - через 3-6 місяців, у 21,67 \% (39) - через 9-12 місяців) спостерігали пубархе. Аксилархе у більшості дівчат з'являлося після пубархе (у 56,11 \% (101) - через 3-6 місяців, у 5,56 \% (10) - через 9-12 місяців) або одночасно з ним (38,33 \% (69)). Середній вік настання телархе склав $(10,34 \pm 0,05)$ року, адренархе - $(11,13 \pm 0,05)$ року, аксилархе $(11,59 \pm 0,07)$ року. Одночасне оволосіння лобка і пахвової западини відбувалося лише у 2,78 \% (5) дівчаток і розглядається нами як одна 3 ознак проявів гіперандрогенії. Менархе, як правило, наставало після телархе, пубархе і аксилархе, при цьому найчастіше на тлі ще недостатньо роз- 
Таблиця 2. Деякі параметри фрізичного розвитку умовно соматично здорових дівчаток Львівської області впродовж пубертатного періоду

\begin{tabular}{|c|c|c|c|c|c|c|c|}
\hline $\begin{array}{c}\text { Вік, } \\
\text { роки }\end{array}$ & $\mathrm{n}$ & $\begin{array}{c}\text { Зріст, } \\
\text { м }\end{array}$ & Маса тіла, кг & $\begin{array}{c}\mathrm{IMT,} \\
\mathrm{\kappa г} / \mathrm{M}^{2}\end{array}$ & $\begin{array}{c}\text { ОГК, } \\
\text { см }\end{array}$ & $\begin{array}{c}\text { ОТ, } \\
\text { см }\end{array}$ & $\begin{array}{c}\text { ОС, } \\
\text { см }\end{array}$ \\
\hline 12 & 30 & $1,52 \pm 0,01$ & $40,00 \pm 0,59$ & $17,32 \pm 0,32$ & $80,07 \pm 0,14$ & $57,25 \pm 0,32$ & $88,00 \pm 0,29$ \\
\hline 13 & 30 & $1,55 \pm 0,01$ & $46,53 \pm 0,33$ & $19,34 \pm 0,15$ & $81,03 \pm 0,24$ & $58,03 \pm 0,24$ & $89,03 \pm 0,24$ \\
\hline 14 & 30 & $1,59 \pm 0,01$ & $49,77 \pm 0,48$ & $19,63 \pm 0,20$ & $83,47 \pm 0,34$ & $60,17 \pm 0,17$ & $92,10 \pm 0,18$ \\
\hline 15 & 30 & $1,63 \pm 0,01$ & $54,67 \pm 0,34$ & $20,53 \pm 0,17$ & $85,63 \pm 0,20$ & $61,63 \pm 0,20$ & $94,13 \pm 0,20$ \\
\hline 16 & 30 & $1,65 \pm 0,01$ & $55,43 \pm 0,69$ & $20,31 \pm 0,23$ & $85,80 \pm 0,36$ & $61,87 \pm 0,36$ & $84,38 \pm 0,37$ \\
\hline 17 & 30 & $1,69 \pm 0,01$ & $58,27 \pm 136$ & $20,36 \pm 0,30$ & $87,93 \pm 0,28$ & $63,95 \pm 0,29$ & $98,88 \pm 0,28$ \\
\hline
\end{tabular}

винених вторинних статевих ознак. У 7,78 \% (14) 12-річних дівчаток мав місце інвертований пубертат, тобто статеве дозрівання починалося не 3 телархе, а з пубархе і/або аксилархе. Темпи статевого дозрівання в період з 12 до 17 років були відносно сталими, про що свідчить і величина сумарного БСР у 12-, 13-, 14-, 15-, 16- і 17-річних дівчат. Рівні БСР, відповідно, були $(4,94 \pm 0,37)$, $(7,91 \pm 0,58),(11,08 \pm 0,25),(11,25 \pm 0,20),(11,86 \pm 0,10)$ і $(11,98 \pm 0,02)$ бала (табл. 3).

Таблиця 3. Параметри статевого розвитку умовно соматично здорових дівчаток Львівської області в динаміці пубертату

\begin{tabular}{|c|c|c|c|c|c|c|c|}
\hline Вік & $\mathrm{n}$ & $\begin{array}{c}\text { Ма, } \\
\text { бали }\end{array}$ & $\begin{array}{c}\text { Ах, } \\
\text { бали }\end{array}$ & $\begin{array}{c}\mathrm{P}, \\
\text { бали }\end{array}$ & $\begin{array}{c}\text { Ме, } \\
\text { бали }\end{array}$ & $\begin{array}{c}\text { Вік менархе, } \\
\text { роки }\end{array}$ & $\begin{array}{c}\text { БСР, } \\
\text { бали }\end{array}$ \\
\hline 12 & 30 & $2,64 \pm 0,09$ & $0,69 \pm 0,04$ & $0,49 \pm 0,03$ & $1,12 \pm 0,28$ & $12,24 \pm 0,08$ & $4,94 \pm 0,37$ \\
\hline 13 & 30 & $3,08 \pm 0,11$ & $0,96 \pm 0,04$ & $0,72 \pm 0,04$ & $3,15 \pm 0,47$ & $12,29 \pm 0,08$ & $7,91 \pm 0,58$ \\
\hline 14 & 30 & $3,52 \pm 0,06$ & $1,16 \pm 0,02$ & $0,87 \pm 0,02$ & $5,53 \pm 0,21$ & $12,47 \pm 0,10$ & $11,08 \pm 0,25$ \\
\hline 15 & 30 & $3,60 \pm 0,01$ & $1,17 \pm 0,02$ & $0,88 \pm 0,01$ & $5,60 \pm 0,18$ & $12,47 \pm 0,10$ & $11,25 \pm 0,20$ \\
\hline 16 & 30 & $3,60 \pm 0,01$ & $1,20 \pm 0,01$ & $0,90 \pm 0,01$ & $6,16 \pm 0,10$ & $12,44 \pm 0,10$ & $11,86 \pm 0,10$ \\
\hline 17 & 30 & $3,60 \pm 0,01$ & $1,19 \pm 0,01$ & $0,89 \pm 0,01$ & $6,30 \pm 0,01$ & $12,56 \pm 0,11$ & $11,98 \pm 0,02$ \\
\hline
\end{tabular}

Збільшення молочних залоз - це найперша ознака початку статевого дозрівання. У групі дівчаток 12 років Ма1 відзначено в 43,33 \% (13), Ma2 - у 40,00 \% (12), Ma3 - в 16,67\% (5); y групі 13 років: Ma1 - у 13,33 \% (4), Ma2 - в 60,00 \% (18), Мa3 - у 26,67\% (8); у групі 14 років: Ma1 - в 6,67 \% (2), Ma2 - у 50,00 \% (15), Ma3 - в 43,33 \% (13); у групі 15 років: Мa1 - у 3,33 \% (1), Ma2 - в 36,67 \% (11) і Ma3 - у 60,00 \% (18); в 16-17 років - Маз було у всіх дівчаток. Таким чином, у 12 років усі обстежені дівчатка вступили на шлях статевого дозрівання, проте в 15 років у 40,00 \% дівчат груди ще не досягли юнацької зрілості. У більшості дівчаток Львівської області телархе спостерігали в 11-12 років, а в 8,89 \% (16) - навіть у 10 років. Тривалість розвитку молочних залоз, ймовірно, становила 4 роки. На перших етапах розвитку молочних залоз мала місце асиметричність їх розвитку. Відсоток дівчаток з одностороннім розвитком молочної залози (Ma1) серед 12-річних склав 2,78 \% (5), а серед 13-річних - 2,22 \% (4) від усіх дівчаток. У цілому у вікових групах асиметричне телархе виявлено у 6,11 \% (11) дівчаток. Середня величина, яка характеризує розвиток молочної залози в 12-, 13-, 14-, 15-, 16- і 17-річних дівчаток, склала,

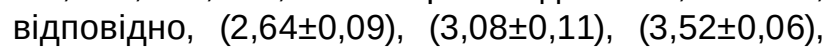
$(3,60 \pm 0,01),(3,60 \pm 0,01)$ і $(3,60 \pm 0,01)$ бала (табл. 3). Максимальна швидкість розвитку даної ознаки припадала на 12-13-річний вік, а після 14 років вона знижувалася, зберігалася на цьому рівні до 17 років.

Вважається, що розвиток молочної залози відбувається під впливом естрогенів, прогестерону і пролактину [7, 11]. У період статевого дозрівання, можливо, відбувається збільшення числа естрогенових і пролактинових рецепторів молочної залози, про що побічно свідчить наявність асиметрії в її розвитку. Збільшення молочних залоз іноді починалося асиметрично, що пов'язано, мабуть, з різною чутливістю залозистої тканини до стимулюючого впливу гормонів. Найчастіше першою збільшувалася ліва залоза; в подальшому ця асиметрія зникала. У обстежених дівчаток розвиток молочних залоз на початкових етапах зачіпав лише ареолу, яка ставала більш соковитою і пігментованою, а далі за цим починалося фрормування залозистої тканини.

Уповільнення швидкості розвитку молочної залози після менархе можна пов'язати з тим, що концентрація пролактину, як відомо [11], досягає максимуму до менархе і зберігається на цьому рівні в наступні роки; в той же час рівень естрогену і прогестерону істотно підвищується після менархе (внаслідок зростання вмісту в крові ФСГ і лг). Не виключено, що саме високі концентрації естрогену і прогестерону знижують чутливість гландулоцитів до пролактину, що проявляється в 
уповільненні збільшення молочної залози. Річна швидкість розвитку молочної залози була максимальною серед обстежених у 12-13 років.

Встановлено, що у 51,67 \% (93) дівчаток паралельно з розвитком молочних залоз починалося оволосіння лобка, при цьому в 26,67\% (48) - через 3-6 місяців, у 21,67 \% (39) - через 9-12 місяців. Таким чином, однією $з$ особливостей пубертатного періоду дівчаток Львівської області можна вважати майже синхронне настання телархе і пубархе. Серед 12-річних дівчаток у 3,33 \% (1) випадків спостерігали інвертований пубертат, тобто пубархе випереджало телархе. У цілому, згідно 3 даними скринінгового дослідження, у 12 років Р1 відзначено в 56,67 \% (17), Р2 - у 36,67 \% (11), P3 - в 6,67 \% (2); у 13 років: Р1 - в 16,67\% (5), P2 у 53,33 \% (16), Р3 - в 30,00 \% (9); у 14 років: Р1 - в 13,33 \% (4), P2 - у 46,67 \% (14), P3 - в 40,00\% (12), а в 15 років Р3 було у всіх пацієнток. Таким чином, пубархе переважно починалося в 11-12 років, однак у 8,89 \% (16) дівчаток оволосіння лобка (як і розвиток молочних залоз) вже спостерігали в 10 років. Тривалість розвитку оволосіння лобка склала 3,5-4 роки. Середня величина в балах, що характеризує оволосіння лобка в 12-, 13-, 14-, 15-, 16- і 17-річних дівчаток, склала, відповідно, $(0,49 \pm 0,03), \quad(0,72 \pm 0,04), \quad(0,87 \pm 0,02), \quad(0,88 \pm 0,01)$, $(0,90 \pm 0,01)$ i $(0,89 \pm 0,01)$ бала (табл. 3). Максимальна швидкість розвитку даної ознаки (як і розвиток молочної залози) припадала на 11-13-річний вік, а в період з 13 років, тобто після менархе вона знижувалася, зберігаючись на цьому рівні до 17 років. Не виключено, враховуючи вікову динаміку продукції естрогенів і андрогенів [2], що зниження темпів лобкового оволосіння після менархе зумовлено зниженням чутливості відповідних рецепторів (або зменшенням концентрації цих рецепторів), розташованих на волосяних цибулинах. Наприклад, можна припустити, що після менархе синтезується нова популяція рецепторів волосяних цибулин, що має меншу спорідненість до естрогенів і андрогенів, в зв'язку з цим інтенсивність росту волосся зменшується.

Оволосіння лобка відбувається під впливом посилення стероїдогенної функції яєчників, тобто продукції естрадіолу і тестостерону в період пубертату. У цілому, багато авторів [2, 9, 15] відзначає, що пубархе, як правило, спостерігали після телархе. У 51,67 \% дівчаток Львівської області пубархе спостерігали одночасно 3 телархе, в 26,67 \% - через 3-6 місяців після телархе і лише у 21,67 \% - через 9-12 місяців.

У препубертатний період (в 8-10 років) підвищується продукція андрогенів корою надниркових залоз, тобто має місце адренархе; при цьому андрогени метаболізуються в естрогени, що може призводити до початкового мізерного оволосіння геніталій до початку істинного пу- бертату. Однак інші автори $[10,12]$ розглядають більш раннє (порівняно 3 телархе) пубархе як інвертований пубертат, пояснюють цю затримку недостатньою продукцією ФСГ і ЛГ. На їхню думку, в цьому випадку оволосіння прогресує дуже повільно і $€$ наслідком впливу надниркових гормонів, а не гормонів статевих залоз. За нашими даними, інвертований пубертат спостерігали в 3,33 \% 12-річних дівчаток Львівської області.

Встановлено, що у 51,11 \% (92) дівчаток аксилархе (оволосіння пахвової западини) настало через 12 місяців після телархе, у 27,78 \% (50) через 3-6 місяців, а в 21,11\% (38) - одночасно 3 телархе. У 5,00 \% (9) дівчаток аксилархе відставало від пубархе на 12 місяців, у 55,00 \% (99) - на 3-6 місяців, а в 40,00 \% (72) дівчаток воно настало одночасно з пубархе. 3 урахуванням цих даних, можна стверджувати, що аксилархе у дівчаток Львівської області спостерігали, як правило, на 12 місяців пізніше телархе і на 3-6 місяців пізніше пубархе.

У групі 12-річних Ах1 відзначено в 36,67\% (11), Ax2 - у 13,33 \% (4), Ax3 - в 0,84 \% (3); у групі 13-річних Aх1 виявлено в 36,67 \% (11), Aх2 у 33,33\% (10), Ах3 - в 10,00 \% (3); серед 14-літніх Ax1 зареєстровано в 30,00\% (9), Ах2 - у 40,00 \% (12), Ах3 - в 20,00\% (6); а серед 15-річних Ах1 відзначали у 13,33 \% (4) випадків, Ах2 в 53,33 \% (16) і Ax3 - у 33,33 \% (10). У групі 16- і 17-річних у всіх випадках спостерігали Ах3. Таким чином, аксилархе в основному спостерігали в 12 і 13 років (відповідно у 60,00 \% і 80,00 \%), хоча у 2,33 \% (7) пацієнток його відзначали раніше - в 11-річному віці. Лише 33,33 \% (10) 15-річних дівчат мали оволосіння пахвових западин, характерне для жінок репродуктивного віку (Aх3). Тому можна вважати, що на відміну від Ма і $\mathrm{P}$, які після 15 років майже не прогресують, розвиток пахвового оволосіння інтенсивно продовжується і після 15 років. 3 цих позицій, ймовірно, Ах3 необхідно розглядати як один із критеріїв завершення статевого дозрівання, оскільки він, швидше за все, проявляється при досить високому рівні статевих гормонів. Привертає увагу той фракт, що відсоток дівчаток, які мали Ах3 в 12 років, досягав 0,84 \%. Побічно, наявність цієї ознаки у 12-річних дівчаток можна розглядати як свідчення передчасного статевого дозрівання. Середня величина в балах, що характеризує оволосіння пахвової западини у 12-, 13-, 14-, 15-, 16- і 17-річних дівчаток, склала, відповідно, $(0,69 \pm 0,04),(0,96 \pm 0,04)$, $(1,16 \pm 0,02), \quad(1,17 \pm 0,02), \quad(1,20 \pm 0,01)$ i $(1,19 \pm 0,01)$ бала (табл. 3). Швидкість розвитку даної ознаки була відносно постійною.

Аксилярний ріст волосся пояснюється впливом на волосяні цибулини андрогенів гонадного і наднирковозалозного походження і меншою мірою - впливом естрогену і прогестерону [2]. На 
особливу увагу заслуговують дані про збіг у часі аксилархе і пубархе. Синхронність аксилархе і пубархе спостерігали в 39,44 \% (71) дівчаток. П̈ї наявність можна пояснити високою чутливістю волосяних цибулин до статевих гормонів або підвищеною активністю гіпофрізарно-надниркової системи. Не виключено, що це зумовлено наявністю в обстежених дівчаток ознак гіперандрогенії.

Річна швидкість розвитку аксилярного оволосіння, на відміну від швидкості розвитку молочної залози і лобкового оволосіння, в період 311 до 15 років у обстежених була відносно постійною. 3 одного боку, це доводить, що механізми, що лежать в основі розвитку аксилярного оволосіння, відрізняються від механізмів, що лежать в основі розвитку молочної залози і лобкового оволосіння. Можливо, це пов'язано з тим, що ріст волосся в пахвових западинах не залежить безпосередньо від концентрації естрогенів і прогестерону в крові. Не виключається також, що гормони, які регулюють розвиток аксилярного оволосіння, переважно мають наднирковий генез, а не гонадний. Тому настання менархе і гормональні зміни, що відбуваються в цей період, не позначаються на швидкості розвитку даної ознаки. 3 іншого боку, як відомо [4], рівень андрогенів (зокрема, тестостерону) до менархе і після менархе залишається постійним. Не виключено, що спочатку під впливом андрогенів на волосяних цибулинах пахвових западин розвиваються тестостеронові рецептори, завдяки яким у подальшому тестостерон і стимулює аксилярне оволосіння. 3 цієї причини, ймовірно, при наявності гіперандрогенії аксилархе нерідко настає одночасно з пубархе.

Після появи всіх вторинних статевих ознак у обстежених дівчаток, як правило, наставало менархе. Середній вік менархе в умовно соматично здорових дівчаток Львівської області склав $(12,43 \pm 0,04)$ року. Показано що в групі 12 років Мe1 відзначено у 26,67 \% (8) випадків, Ме2 - в 13,33\% (4); у групі 13 років Ме1 зареєстровано в 10,00 \% (3) пацієнток, Ме2 - у 30,00 \% (9),
Me3 - в 26,67 \% (8); в 14 років Me1 не спостерігали, Мe2 було в 30,00 \% (10) випадків, Ме3 - у 66,67\% (20); в 15 років ознаку Ме2 відзначено у 6,67 \% (2) дівчаток, Ме3 - в 93,33 \% (28). У групах 16- і 17-річних дівчат у всіх випадках реєстрували Ме3. Наші дані свідчать про те, що 53,33 \% (16) 15-річних дівчат мали несталий менструальний цикл. Середня величина, яка характеризує становлення менструальної фрункції у 12-, 13-, 14-, 15-, 16- і 17-річних дівчаток, склала, відповідно, $(1,12 \pm 0,28),(3,15 \pm 0,47),(5,53 \pm 0,21),(5,60 \pm 0,18)$, $(6,16 \pm 0,10)$ і $(6,30 \pm 0,01)$ бала (табл. 3). Швидкість розвитку менструальної функції в період з 12 до 15 років поступово збільшувалася, досягала максимуму в 14 років (після менархе), а після 15 років вона незначно знижувалася.

Розрахунки показують, що середня маса 12-річних дівчаток склала $(40,00 \pm 0,59)$ кг, зріст $(1,52 \pm 0,01)$ м, IMT - $(17,32 \pm 0,32)$ кг/м²; для 13-річних дівчаток ці значення склали, відповідно, $(46,53 \pm 0,33)$ кг, $(1,55 \pm 0,01) \mathrm{M},(19,34 \pm 0,15) \mathrm{\kappa} / \mathrm{M}^{2}$. Оскільки середній вік менархе у дівчаток Львівської області склав $(12,43 \pm 0,04)$ року, то представлені дані дозволяють вважати, що менархе настає при середній масі тіла не менше за 37 кг. У літературі постійно обговорюють питання про залежність віку менархе від антропометричних показників [5, 14]. Вважається, що менархе настає після того, як дівчинка досягає певної маси тіла (44-49 кг) і певного зросту (151,5-159,5 см). Менархе, дійсно, настає при досягненні певних значень маси тіла, зросту та інших антропометричних показників, конкретні значення яких, також як і вік менархе, ймовірно, визначаються генетичними фракторами.

\section{Висновки}

Статевий розвиток умовно соматично здорових дівчаток Львівської області відповідає встановленим віковим нормам української популяції.

Перспективи подальших досліджень полягають в оцінці статевого розвитку умовно соматично здорових дівчаток Львівської області в постпубертатний період.

\section{Список літератури}

1. Вовк І. Б. Порушення статевого розвитку у дівчаток / І. Б. Вовк, В. К. Кондратюк, В. Ф. Петербурзька // Здоров'я України. - 2016. - № 1 (21). - С. 51-53.

2. Гінекологія дитячого і підліткового віку : підручник / за ред. І. Б. Вовк, О. М. Юзька, В. П. Вдовиченка. - К. : ВСВ «Медицина», 2011. - 424 с.

3. Ранняя диагностика задержки развития женской половой системы : методические рекомендации МЗ УССР / л. Т. Волкова, В. Г. Васильева, Л. И. Слинько [и др.]. - Харьков, 1979. - 16 с.

4. Adolescents and androgens, receptors and rewards / S. M. Sato, K. M. Schulz, C. L. Sisk, R. I. Wood // Horm. Behav. 2008. - Vol. 53 (5). - P. 647-658.

5. BMI relationship to the onset of puberty: assessment of growth parameters and sexual maturity changes in Egyptian children and adolescents of both sexes / S. S. Abou El Ella, N. F. Barseem [et al.] // J. Pediatr. Endocrinol. Metab. - 2020. Vol. 33 (1). - P. 121-128.

6. Coast $E$. Puberty and menstruation knowledge among young adolescents in low- and middle-income countries: a scoping review / E. Coast, S. R. Lattof, J. Strong // Int. J. Public Health. - 2019. - Vol. 64 (2). - P. 293-304. 
7. De Silva N. K. Breast development and disorders in the adolescent female / N. K. De Silva // Best Pract. Res. Clin. Obstet. Gynaecol. - 2018. - Vol. 48. - P. 40-50.

8. Developmental differences in reward sensitivity and sensation seeking in adolescence: Testing sex-specific associations with gonadal hormones and pubertal development / K. P. Harden, F. D. Mann, A. D. Grotzinger [et al.] // J. Pers. Soc. Psychol. - 2018. - Vol. 115 (1). - P. 161-178.

9. Kota A. S. Precocious puberty / A. S. Kota, S. Ejaz / In: StatPearls [Electronic resource]. - Treasure Island (FL): StatPearls Publishing, 2020. (Last Update: July 10, 2020).

10. Novello L. Premature Adrenarche / L. Novello, P. W. Speiser // Pediatr. Ann. - 2018. - Vol. 47 (1). - e7-e11.

11. Pubertal timing and breast density in young women: a prospective cohort study / L. C. Houghton, S. Jung, R. Troisi [et al.] // Breast Cancer Res. - 2019. - Vol. 21 (1). - P. 122.

12. Reference values for serum dehydroepiandrosterone-sulphate in healthy children and adolescents with emphasis on the age of adrenarche and pubarche / T. Guran, I. Firat, F. Yildiz [et al.] // Clin. Endocrinol. (Oxf). - 2015. - Vol. 82 (5). P. $712-728$.

13. Tanner J. M. Growth at Adolescence. - 2nd ed. / J. M. Tanner. - Oxford: Blackwell Scientific Publications, $1962 .-325$ p. 14. The relationship between obesity and body compositions with respect to the timing of puberty in Chongqing adolescents: a cross-sectional study / F. He, P. Guan, Q. Liu [et al.] // BMC. Public Health. - 2017. - Vol. 17 (1). - P. 664.

15. Timing of puberty in boys and girls: A population-based study / N. Brix, A. Ernst, L. Lauridsen [et al.] // Paediatr. Perinat. Epidemiol. - 2019. - Vol. 33 (1). - P. 70-78.

\section{References}

1. Vovk, I.B., Kondratiuk, V.K., \& Peterburzka, V.F. (2016). Porushennia statevoho rozvytku u divchatok [Sexual development disorders in girls]. Zdorovia Ukrainy - Health of Ukraine, 1 (21), 51-53 [in Ukrainian].

2. Vovk, I.B., Yuzka, O.M., \& Vdovychenka, V.P. (2011). Hinekolohiia dytiachoho i pidlitkovoho viku: pidruchnyk [Gynecology of children and adolescents: a textbook]. Kyiv: VSV «Medytsyna» [in Ukrainian].

3. Volkova, L.T., Vasileva, V.G., \& Slinko, L.I. (1979). Rannyaya diagnostika zaderzhki razvitiya zhenskoy polovoy sistemy: Metodicheskie rekomendatsii MZ USSR [Methodological recommendations of the Ministry of Health of the USSR]. Kharkiv [in Russian].

4. Sato, S.M., Schulz, K.M., Sisk, C.L, \& Wood, R.I. (2008). Adolescents and androgens, receptors and rewards. Horm. Behav., 53 (5), 647-658. DOI: 10.1016/j.yhbeh.2008.01.010.

5. Abou El Ella, S.S., Barseem, N.F., Tawfik, M.A., \& Ahmed, A.F. (2020). BMI relationship to the onset of puberty: assessment of growth parameters and sexual maturity changes in Egyptian children and adolescents of both sexes. J. Pediatr. Endocrinol. Metab., 33 (1), 121-128. DOI: 10.1515/jpem-2019-0119.

6. Coast, E., Lattof, S.R., \& Strong, J. (2019). Puberty and menstruation knowledge among young adolescents in low- and middle-income countries: a scoping review. Int. J. Public Health, 64 (2), 293-304. DOI: 10.1007/s00038-019-01209-0.

7. De Silva, N.K. (2018). Breast development and disorders in the adolescent female. Best Pract. Res. Clin. Obstet. Gynaecol., 48, 40-50. DOI: 10.1016/j.bpobgyn.2017.08.009.

8. Harden, K.P., Mann, F.D., Grotzinger, A.D., Patterson, M.W., Steinberg, L., Tackett, J.L., \& Tucker-Drob, E.M. (2018). Developmental differences in reward sensitivity and sensation seeking in adolescence: Testing sex-specific associations with gonadal hormones and pubertal development. J. Pers. Soc. Psychol., 115 (1), 161-178. DOI: 10.1037/pspp0000172. 9. Kota, A.S., \& Ejaz, S. (2020). Precocious Puberty. In: StatPearls Treasure Island (FL): StatPearls Publishing (Last Update: July 10, 2020).

10. Novello, L., \& Speiser, P.W. (2018). Premature Adrenarche. Pediatr. Ann., 47 (1), e7-e11. DOI: 10.3928/1938235920171214-04.

11. Houghton, L.C., Jung, S., Troisi, R., LeBlanc, E.S., Snetselaar, L.G., Hylton, N.M., ..., \& Dorgan, J.F. (2019). Pubertal timing and breast density in young women: a prospective cohort study. Breast Cancer. Res., 21 (1), 122. DOI: 10.1186/ s13058-019-1209-x.

12. Guran, T., Firat, I., Yildiz, F., Kaplan Bulut, I., Dogru, M., \& Bereket, A. (2015). Reference values for serum dehydroepiandrosterone-sulphate in healthy children and adolescents with emphasis on the age of adrenarche and pubarche. Clin. Endocrinol. (Oxf)., 82 (5), 712-718. DOI: 10.1111/cen.12612.

13. Tanner, J.M. (1962). Growth at Adolescence. 2nd ed. Oxford: Blackwell Scientific Publications.

14. He, F., Guan, P., Liu, Q., Crabtree, D., Peng, L., \& Wang, H. (2017). The relationship between obesity and body compositions with respect to the timing of puberty in Chongqing adolescents: a cross-sectional study. BMC. Public Health, 17 (1), 664. DOI: 10.1186/s12889-017-4681-1.

15. Brix, N., Ernst, A., Lauridsen, L., Parner, E., Støvring, H., Olsen, J., ..., \& Ramlau-Hansen, C.H. (2019). Timing of puberty in boys and girls: A population-based study. Paediat. Perinat. Epidemiol., 33 (1), 70-78. DOI: 10.1111/ppe.12507.

\section{SEXUAL DEVELOPMENT OF CONDITIONALLY SOMATICALLY HEALTHY GIRLS IN LVIV REGION DURING PUBERTY}

E. F. Chaikivska

Danylo Halytsky Lviv National Medical University, Lviv, Ukraine

Purpose: to assess the sexual development of conventionally somatically healthy girls in Lviv region during puberty. 
Materials and Methods. There were examined 180 conditionally somatically healthy girls from Lviv region aged 12 to 17 years. Anthropometric studies (measuring height, body weight and calculating body mass index, measuring the circumference of the chest, waist, hips) and assessing sexual development based on the aggregate development of secondary sexual characteristics (pubic and axillary hairiness, the development of the mammary glands and the onset of menstruation J. M. Tanner and L.G. Tumilovich) were carried out.

Results. In $92.78 \%$ of cases, puberty of conventionally somatically healthy girls from Lviv region began with thelarche. The average age of onset of thelarche was $(10.34 \pm 0.05)$ years, adrenarche $-(11.13 \pm 0.05)$ years, axillarche $-(11.59 \pm 0.07)$ years, menarche - $(12.43 \pm 0.04)$ years. A characteristic feature was the development of thelarche together with pubarche in $51.67 \%$ of girls and axillarche with pubarche - in $39.44 \%$ of girls. Menarche, as a rule, came after thelarche, pubarche and axillarche, with an average body weight of at least $37 \mathrm{~kg}$, most often against the background of still insufficiently developed secondary sexual characteristics. In $3.33 \%$ of cases, an inverted puberty was observed, that is, pubarche was ahead of thelarche. In $5.00 \%$ of girls, the axillarche lagged behind the pubarche by 12 months, in $55.00 \%$ - by 3-6 months, and in $40.00 \%$ of girls it occurred simultaneously with the pubarche. The rates of puberty in the period from 12 years to 17 years were relatively stable, as evidenced by the value of the total score of sexual development in 12-, 13-, 14-, 15-, 16- and 17-yearold girls - the values of the score of sexual development were respectively $(4.94 \pm 0.37),(7.91 \pm 0.58),(11.08 \pm 0.25)$, (11.25 \pm 0.20$),(11.86 \pm 0.10)$ and $(11.98 \pm 0.02)$ points.

Conclusions. The sexual development of conditionally somatically healthy girls in Lviv region corresponds to the established age norms of the Ukrainian population.

KEY WORDS: girls; Lviv region; physical development; puberty; thelarche; adrenarche; axillarche; menarche.

Рукопис надійшов до редакції 18.09.2020 p.

\section{Відомості про автора:}

Чайківська Еліна Флавіанівна - кандидат медичних наук, доцент кафредри акушерства, гінекології та перинатології фракультету післядипломної освіти Львівського національного медичного університету імені Данила Галицького, головний позаштатний спеціаліст з дитячої та підліткової гінекології Львівської області. 